Atmos. Chem. Phys., 1, 9-18, 2001

www.atmos-chem-phys.org/acp/1/9/

\title{
Coastal zone production of IO precursors: a 2-dimensional study
}

\author{
L. J. Carpenter ${ }^{1}$, K. Hebestreit ${ }^{2}$, U. Platt ${ }^{2}$, and P. S. Liss ${ }^{3}$ \\ ${ }^{1}$ Department of Chemistry, University of York, York, YO10 5DD, UK \\ ${ }^{2}$ Institut für Umweltphysik, University of Heidelberg, INF 229, D-69120 Heidelberg, Germany \\ ${ }^{3}$ School of Environmental Sciences, University of East Anglia, Norwich, NR4 7TJ, UK
}

Received 13 August 2001 - Published in Atmos. Chem. Phys. Discuss. 3 September 2001

Revised 8 November 2001 - Accepted 9 November 2001 - Published 23 November 2001

\begin{abstract}
At Mace Head, Eire, in the coastal East Atlantic, diiodomethane has been identified as an important precursor of iodine oxide radicals. Peak concentrations of both $\mathrm{CH}_{2} \mathrm{I}_{2}$ and $\mathrm{IO}$ at low water indicate that the intertidal region is a strong source of organo-iodines. Atmospheric measurements of $\mathrm{CH}_{2} \mathrm{I}_{2}$ made in marine air are compared with the concentrations predicted by a 2-dimensional model incorporating horizontal and vertical dispersion of surface emissions. The model shows that micrometeorological variability, proximity of the site to emissions, and photolysis all play important roles in determining the $\mathrm{CH}_{2} \mathrm{I}_{2}$ concentrations at Mace Head. In addition to a tidal-height dependent intertidal flux, which was estimated from seaweed production data, a contribution from offshore (non-local) sources was required in order to reproduce the strong signature of photolysis in the $\mathrm{CH}_{2} \mathrm{I}_{2}$ observations. A combination of an offshore flux and an intertidal flux (of up to $1.4 \times 10^{9}$ molecules $\mathrm{cm}^{-2} \mathrm{~s}^{-1}$ at low water) results in good agreement between the measured and modelled $\mathrm{CH}_{2} \mathrm{I}_{2}$ concentrations. Although this study does not necessarily infer emission of $\mathrm{CH}_{2} \mathrm{I}_{2}$ from the open ocean, it suggests that air-sea exchange of $\mathrm{CH}_{2} \mathrm{I}_{2}$ in coastal waters does occur.
\end{abstract}

\section{Introduction}

During the last decade it was established that catalytic cycles involving halogen oxide radicals $(\mathrm{BrO}$ with smaller contributions from $\mathrm{IO}$ and $\mathrm{ClO}$ ) were responsible for rapid ozone depletion events in the Arctic boundary layer during spring (Barrie et al., 1988; Bottenheim et al., 1990; Barrie and Platt, 1997). More recently, the IO radical has been identified in Antarctica (Friess et al., 2001) and in the mid-latitudes (Alicke et al., 1999; Allan et al., 2000) in conjunction with organoiodine precursors (Carpenter et al., 1999), confirming

Correspondence to: L. J. Carpenter (ljc4@york.ac.uk) the potential for the more widespread occurrence of boundary layer ozone depletion. Formation of IO is driven by ocean-atmosphere exchange of organo-iodines that are photolysed quickly within the marine boundary layer. Previous studies at Mace Head found that a range of photolabile iodine containing organics including $\mathrm{CH}_{3} \mathrm{I}, \mathrm{C}_{2} \mathrm{H}_{5} \mathrm{I}, \mathrm{CH}_{2} \mathrm{ICl}$, $\mathrm{CH}_{2} \mathrm{IBr}$ and $\mathrm{CH}_{2} \mathrm{I}_{2}$ were present in sufficiently high concentrations to sustain IO levels of a few parts per trillion (ppt), via the following reactions:

$$
\begin{aligned}
& \mathrm{RI} \stackrel{h v}{\longrightarrow} \mathrm{R}+\mathrm{I} \\
& \mathrm{I}+\mathrm{O}_{3} \rightarrow \mathrm{IO}+\mathrm{O}_{2}
\end{aligned}
$$

Of the organoiodines measured, $\mathrm{CH}_{2} \mathrm{I}_{2}$ was found to be the most important iodine precursor (Carpenter et al., 1999). The photodissociation lifetime of diiodomethane is only a few minutes at midday (Mössinger et al., 1998).

The impact of IO on ozone concentrations depends on the detailed gas phase and heterogeneous chemistry following reaction (2). Computational modelling investigations indicate that the rate of ozone destruction associated with iodine photochemistry in the marine boundary layer could equal that from $\mathrm{HO}_{\mathrm{x}}$ photochemistry (Vogt et al., 1999; Stutz et al., 1999; McFiggans et al., 2000). Perhaps of even greater uncertainty are the emissions and distributions of iodine precursors. Shipboard experiments have identified $\mathrm{CH}_{2} \mathrm{ICl}$ (Klick and Abrahamsson, 1992; Schall et al., 1997) and $\mathrm{CH}_{2} \mathrm{I}_{2}$ (Schall et al., 1997) in the open ocean, although it is not yet established whether these originate from microalgae (phytoplankton) or other (e.g. photochemical) sources. That coastal macroalgae are prolific emitters of a wide range of organic halogens is without doubt (e.g. Gschwend et al., 1985; Nightingale et al., 1995; Pedersén et al., 1996; Carpenter et al., 2000 and references therein), although the global budgets of seaweed emissions are very uncertain.

During the ACSOE (Atmospheric Chemistry Studies in the Oceanic Environment) experiment at Mace Head in 1997, 


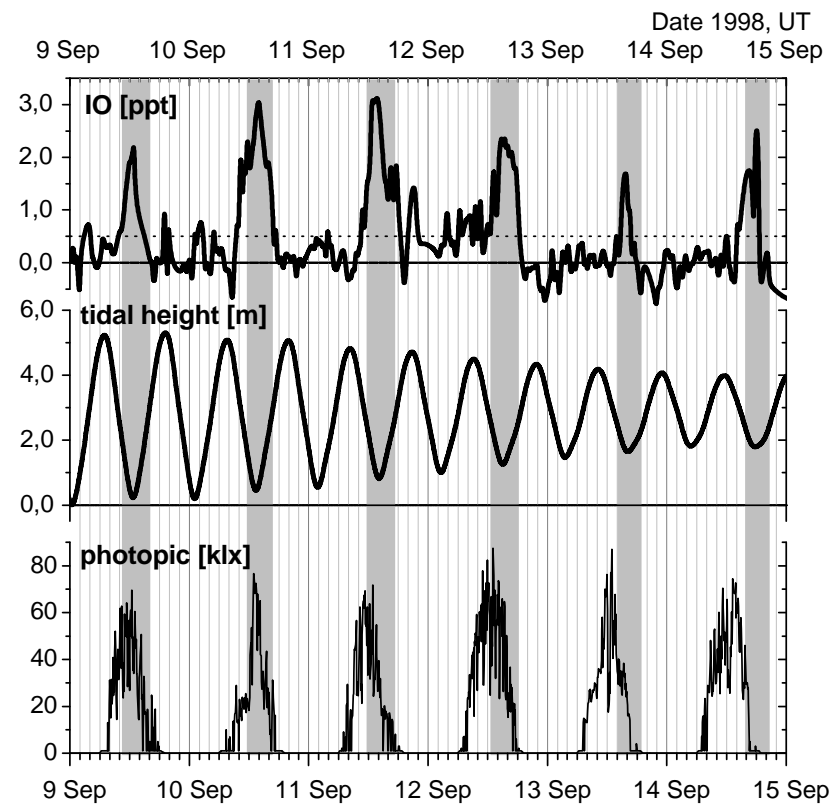

Fig. 1. IO, tidal height and solar radiation (as photopic flux) during 9-15 September 1998. The dotted line on the IO graph represents the average detection limit. The grey areas mark the low tide periods during the day.

macroalgal emissions were observed to have a direct impact on the local atmosphere, as reflected by the peak air concentrations of polyhalogenated halocarbons occurring at low water (Carpenter et al., 1999). These observations may be attributed to direct emission into the surrounding air from exposed macroalgae at low tide and/or increased emissions due to oxidative stress of algae upon exposure (Carpenter et al., 2000). At high tide, emissions from submerged beds are diluted in seawater and may undergo photolysis before exchange at the air-sea interface.

Measurements of organo-iodines and IO radicals at Mace Head were repeated during the 1998 EU project PARFORCE (New Particle Formation and Fate in the Coastal Environment). In this study we attempt to evaluate the relative importance of coastal and offshore emissions of $\mathrm{CH}_{2} \mathrm{I}_{2}$, providing further information on sources of the IO radical. A 2dimensional model is used to predict the horizontal and vertical distributions of $\mathrm{CH}_{2} \mathrm{I}_{2}$ resulting from coastal and offshore (non-local) emissions.

\section{Experimental}

Mace Head is located on the remote western coast of County Galway, Eire $\left(53^{\circ} 19^{\prime} \mathrm{N}, 9^{\circ} 54^{\prime} \mathrm{W}\right)$. The site is well known for background air measurements and receives relatively clean marine air from the prevailing westerly sector associated with the easterly tracking cyclonic systems of the North At-

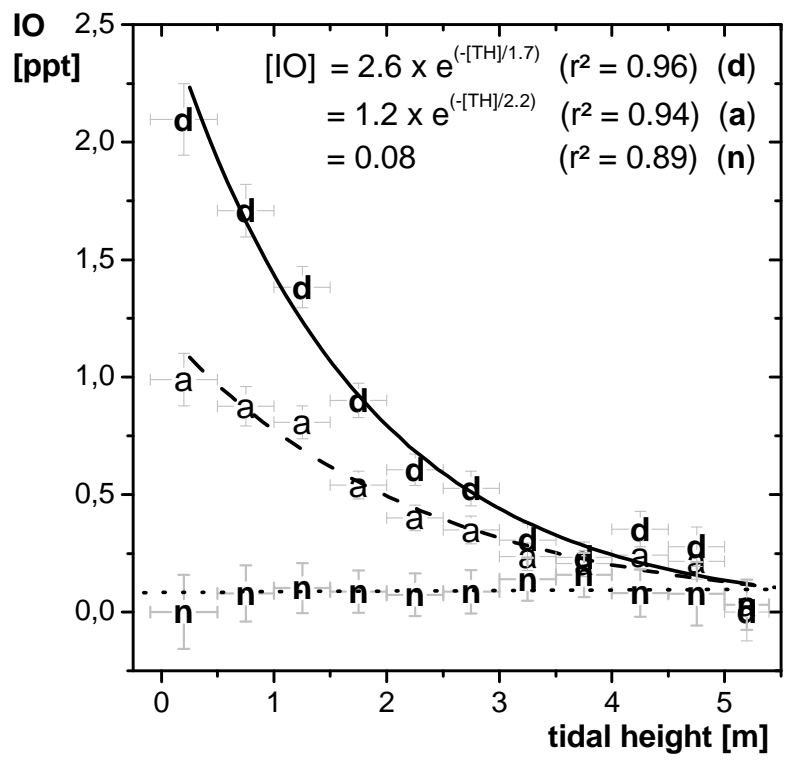

$$
\begin{aligned}
& \mathrm{n}=\text { night } \\
& \mathrm{d}=\text { day } \\
& \mathrm{a}=\text { all data }
\end{aligned}
$$

Fig. 2. Correlation of IO and tidal height (TH) during PARFORCE (whole data set). The data points are binned averages of $0.5 \mathrm{~m}$ segments of TH. The vertical error bars represents the relative frequency of the data, the horizontal error bars the length of the respective interval. The day-time data and all data fitted with an exponentially decreasing trend, the night-time data has a linear fit.

lantic. The rocky upper littoral zone and cold waters provide favourable conditions for seaweeds.

\subsection{Halocarbons}

During the period 5-24 September 1998, halocarbons in air were monitored in-situ every 40 minutes with a Hewlett Packard 6890/5973 gas chromatograph/mass spectrometer (GC/MS) system. The GC/MS was operated in a laboratory situated ca. $100 \mathrm{~m}$ from the high tide mark, with a sampling inlet located with an open fetch to the ocean at a height of approx. $12 \mathrm{~m}$ above mean sea level (MSL). The system is developed for automated air sampling and is described fully in Carpenter et al. (1999). Analysis was also performed on discrete samples of surface seawater and the water surrounding incubated seaweeds. For a full description of analytical procedures for air and seawater analyses during PARFORCE see Carpenter et al. (2000).

\subsection{IO measurements by DOAS}

Over a 1-month period from 8 September until 8 October 1998 LP DOAS (Long-Path Differential Optical Absorption Spectroscopy; Platt, 1994) measurements of the halogen ox- 


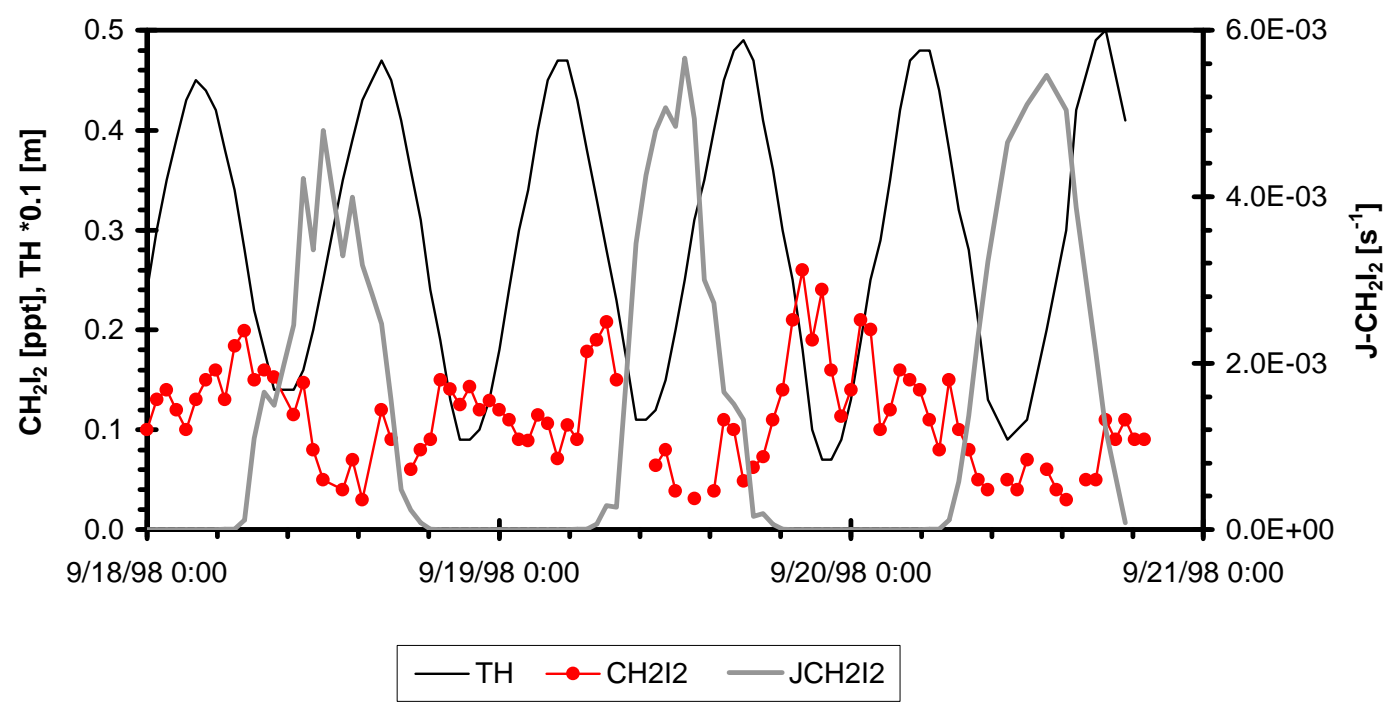

Fig. 3. $\mathrm{CH}_{2} \mathrm{I}_{2}$, tidal height and calculated $\mathrm{J}-\mathrm{CH}_{2} \mathrm{I}_{2}$ during clean marine conditions.

ides $\mathrm{IO}, \mathrm{OIO}$ and $\mathrm{BrO}$ and of other atmospheric trace gases including $\mathrm{NO}_{2}, \mathrm{O}_{3}, \mathrm{HCHO}, \mathrm{HONO}$ and $\mathrm{NO}_{3}$ were carried out whenever the visibility allowed reasonable signal to noise ratios.

Briefly, the principle of DOAS is the identification and quantification of atmospheric trace gases by their specific narrow $(<5 \mathrm{~nm})$ band optical absorption structure in the open atmosphere, separating trace gas absorption from broad band molecule and aerosol extinction processes, thus allowing very sensitive detection of many molecular species (see e.g. Platt and Perner, 1983). The identification of the gases is unambiguous since their specific absorption structure is, similar to a fingerprint, unique. Calibration of the instrument is not necessary as long as the absorption cross section is known.

A DOAS instrument based on the principle of Platt and Perner (Platt and Perner, 1983) was used at Mace Head. It incorporates a combination of two coaxially arranged Newtonian telescopes, one collimating the light of a Xe-shortarc lamp through the atmosphere, the second recollecting the beam reflected by an array of quartz prism retroreflectors. The telescopes were set up in a laboratory about 20 meters from the shore, while the retroreflector array was placed on the northern shore of the bay. The light beam was running at an average height of 10 meters above the ocean with a light path length of $2 \times 7.27 \mathrm{~km}$. A $0.5 \mathrm{~m}$ Czerny-Turner spectrograph $(f=6.9,600 \mathrm{gr} / \mathrm{mm}$ grating, thermostated to $30 \pm 0.3^{\circ} \mathrm{C}$ ), in combination with a 1024 pixel photodiode array detector (thermostated to $-15 \pm 0.3^{\circ} \mathrm{C}$ ), was coupled to the telescope by a quartz fibre, which also performed the task of a mode mixer (Stutz and Platt, 1997). Iodine oxide was measured in the wavelength range from 414 to $437 \mathrm{~nm}$ with a spectral resolution of about $0.5 \mathrm{~nm}$ (a dispersion of
$0.078 \mathrm{~nm} / \mathrm{pixel})$. Three further wavelength regions were chosen to detect $\mathrm{BrO}(335 \pm 40 \mathrm{~nm})$ (Hönninger, 1999), OIO $(550 \pm 40 \mathrm{~nm})$ (Hebestreit, 2001), $\mathrm{NO}_{3}(645 \times 40 \mathrm{~nm})$ and the other species absorbing in the respective wavelength regions $\left(\mathrm{O}_{3}, \mathrm{SO}_{2}, \mathrm{NO}_{2}, \mathrm{HCHO}, \mathrm{HONO}\right)$. Besides $\mathrm{NO}_{3}$, all spectra were recorded using the multi channel scanning technique (Brauers et al., 1995). The concentrations of IO were derived using a least squares fit mixer (Stutz and Platt, 1997) of the reference spectra of $\mathrm{H}_{2} \mathrm{O}, \mathrm{NO}_{2}$ and $\mathrm{IO}$, together with a sixth order polynomial to the atmospheric absorption spectrum. The IO reference spectrum was measured in our laboratory, since no absorption cross section of sufficient resolution was available. $\mathrm{NO}_{2}$ was measured in a reference cell in the field. Absolute values for both spectra were determined by comparison with literature cross sections (Cox et al., 1999; Harder et al., 1997; Hönninger, 1999). The $\mathrm{H}_{2} \mathrm{O}$ reference was calculated by a convolution of the instrument function with the absorption cross section of the HITRAN database (HITRAN, 1987).

\subsection{Model description}

A 3-day period (18-20 September 1998, Julian days 261-263) of clean marine south-westerly air with stable temperatures $\left(17.2 \pm 1.9^{\circ} \mathrm{C}\right)$ and wind speed $(5.5 \pm$ $1.0 \mathrm{~m} \mathrm{~s}^{-1}$ ) was selected as a case study for evaluation of marine emissions. Data were evaluated using a model written in the FACSIMILE language. The photolysis rate of diiodomethane $\left(\mathrm{J}^{-} \mathrm{CH}_{2} \mathrm{I}_{2}\right)$ was computed at 40 minute intervals using a 2 -stream radiative transfer model (Hough, 1988), with absorption cross-sections from Mössinger et al. (1998) and TOMS $\mathrm{O}_{3}$ column data (http://toms.gsfc.nasa.gov/ozone/ozone01.html). Photolysis rates were corrected for cloud cover using the ratio of mea- 

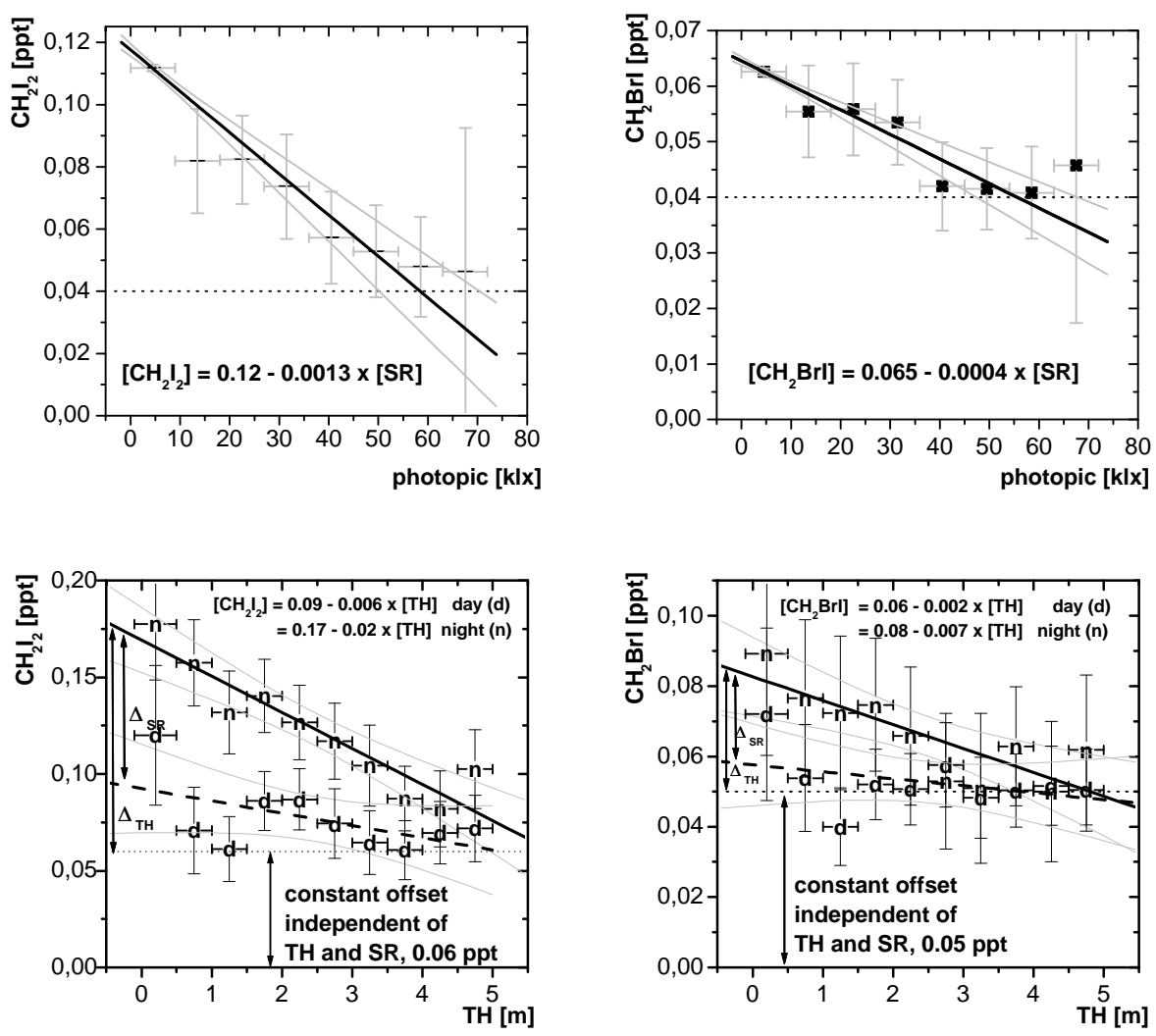

Fig. 4. Correlations of $\mathrm{CH}_{2} \mathrm{I}_{2}$ and $\mathrm{CH}_{2} \mathrm{IBr}$ with solar radiation (SR) and tidal height (TH) for the whole measurement period. The data points are binned averages of $0.5 \mathrm{~m}$ segments of TH. The vertical error bars represents the relative frequency of the data, the horizontal error bars the length of the respective interval. The correlation with $\mathrm{TH}$ is divided into night-time (n) and day-time $(\mathrm{d})$ values of $\mathrm{CH}_{2} \mathrm{I}_{2}$ and $\mathrm{CH}_{2} \mathrm{IBr}$, respectively.

sured/modelled UVA data. The 2-dimensional model incorporated a $5.2 \mathrm{~km}$ long by $50 \mathrm{~m}$ high slice through the atmosphere divided into cells of $100 \mathrm{~m}$ length and $2 \mathrm{~m}$ height. The first $5 \mathrm{~km}$ of the horizontal axis represented the "offshore" region, the next $100 \mathrm{~m}$ represented the intertidal region, and the Mace Head site was notionally located in the final $100 \mathrm{~m}$ cell, at $12 \mathrm{~m}$ height (the sampling height of $\mathrm{CH}_{2} \mathrm{I}_{2}$ ). $\mathrm{CH}_{2} \mathrm{I}_{2}$ was emitted into the bottom cell and transported across consecutive cell faces using the finite volume method to discretise the spatial partial derivatives, given by:

$\frac{\partial C}{\partial t}=Q+D \frac{\partial^{2} C}{\partial x^{2}}-u \frac{\partial C}{\partial x}$

where $C$ is the concentration of $\mathrm{CH}_{2} \mathrm{I}_{2}, Q$ is the net rate of production and destruction, $D$ is the diffusion coefficient (set to zero for horizontal transport), the third term representing advection, with $u$ the horizontal wind speed. Horizontal wind speed was parameterised with 40-minute averages of the measured mean values at $3 \mathrm{~m}$ height (de Leeuw et al., 2001). Measurements made at $18 \mathrm{~m}$ were typically $\sim 25 \%$ higher (de Leeuw et al., 2001) as expected from the logarithmic dependence of wind speed with height and a roughness length, $z_{0}$, of $\sim 10^{-4} \mathrm{~m}$ (Kunz et al., 2000). Locally, the extent of the sloping terrain upwind of the site will vary with tidal height, adding to some variability in the roughness length.

The rate of transport across the vertical boundary faces of each cell was described by replacing $\partial x$ with $\partial z$ and the eddy diffusivity coefficient, $K_{z}$, in place of $D$. The diffusivity coefficient was assumed to vary with height in the surface layer according to (cf. Stull, 1988):

$K_{z}=\frac{\kappa u_{*} z}{\phi(z / L)}$

where $\kappa$ is the von Karman constant $(\kappa=0.4), z$ is height, $u *$ is the friction velocity and $\phi(z / L)$ is a stability correction equal to unity during neutrally stratified boundary layer conditions, which prevailed at Mace Head (de Leeuw et al., 2001). During PARFORCE, de Leeuw et al. (2001) found that the friction velocity in marine sector air was approximately equal to $9 \%$ of the wind speed at $3 \mathrm{~m}$, a relationship which was used to define $u *$ in the model. Formation of an internal boundary layer (IBL) would lead to abrupt changes in the diffusivity gradient at heights determined by the distance from the shoreline. It is difficult to assess the impact of 


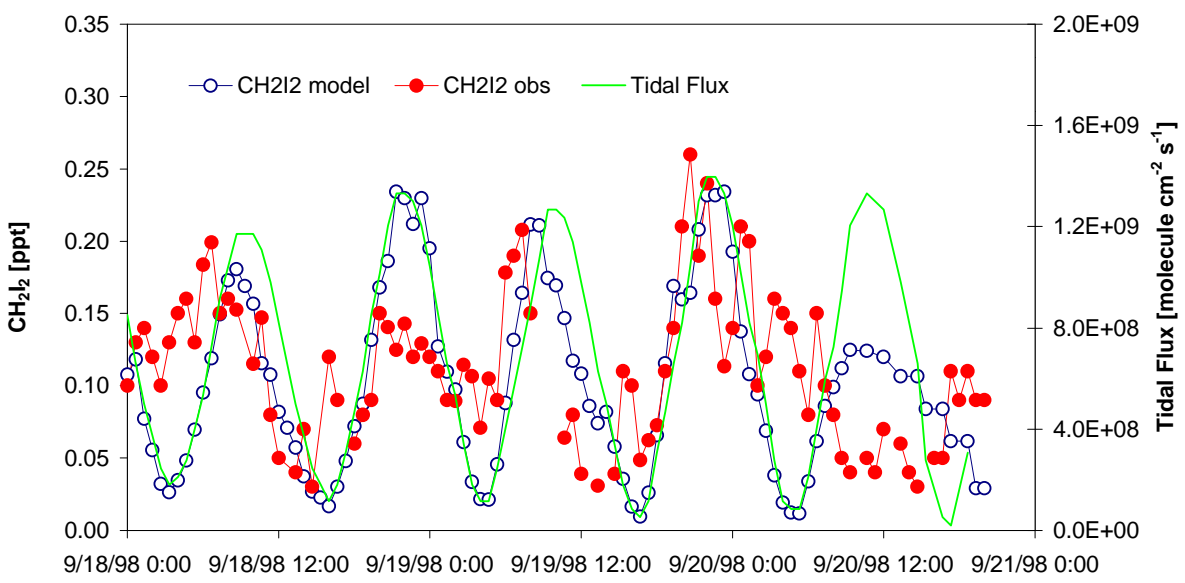

Fig. 5. Comparison of measured and modelled $\mathrm{CH}_{2} \mathrm{I}_{2}$ levels assuming only tidal emissions, shown with the tidal flux used in the model.

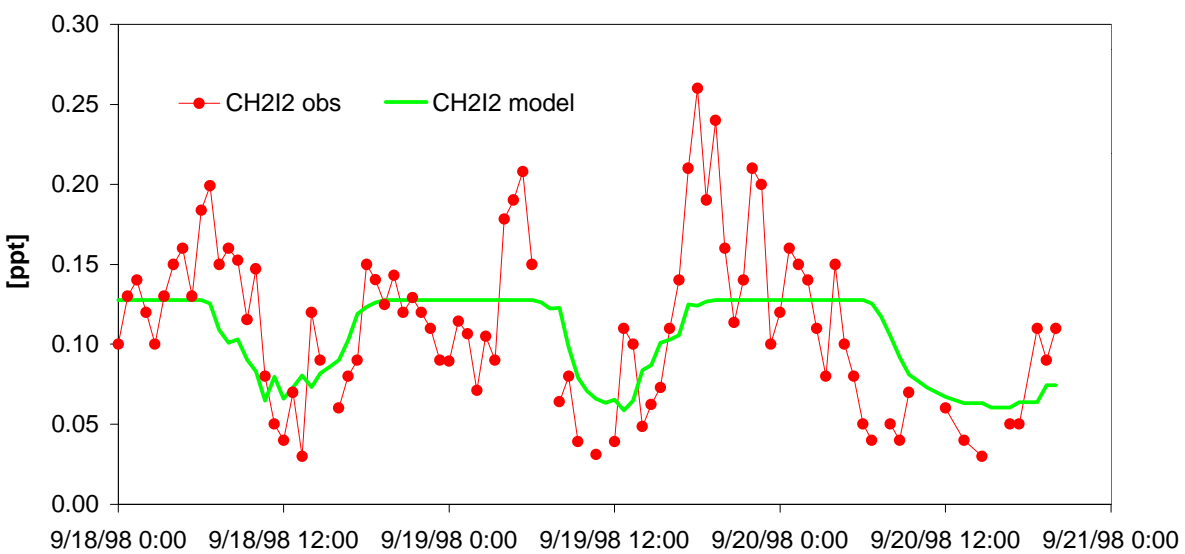

Fig. 6. Comparison of measured and modelled $\mathrm{CH}_{2} \mathrm{I}_{2}$ levels assuming only offshore emissions (constant wind speed and $K$ ).

IBL formation on the conclusions of this study, but we note the additional uncertainty.

\section{Results and discussion}

3.1 Relationships of iodine species with tidal height and solar radiation

Analysis of PARFORCE data showed that tidal height (TH) and solar radiation (SR) were correlated with $\mathrm{CH}_{2} \mathrm{I}_{2}, \mathrm{IO}$, and to a lesser extent, $\mathrm{CH}_{2} \mathrm{IBr}$ air concentrations. Figure 1 shows IO, tidal height and solar radiation at $555 \mathrm{~nm}$ (photopic flux in $\mathrm{kW} / \mathrm{m}^{2}=\mathrm{klx}$ ) for the period 9-15 September. The figure shows that the maximum IO concentrations occurred during the day at low tide. The daily IO maximum shifted simultaneously with the minimum in $\mathrm{TH}$ (about one hour from day to day), indicating that both solar flux and tidal height controlled the time of the IO peak. There is an IO peak after sunset on the evening of the 14 September, however the IO signal during this period was below the detection limit, which increased substantially at that time due to fog. Figure 2 shows correlations of IO versus TH for daytime values only $(\boldsymbol{d})$, all data $(\boldsymbol{a})$, and night-time values $(\boldsymbol{n})$ of the 4 week measurement period. Under daylight conditions, high IO values were clearly associated with low tidal height, while at night no correlation between IO and TH was found. The correlation was described well by an exponential decrease with rising tide $\left(r^{2}=0.96\right)$.

Figure 3 shows tidal height, $\mathrm{CH}_{2} \mathrm{I}_{2}$ concentrations and calculated $\mathrm{J}-\mathrm{CH}_{2} \mathrm{I}_{2}$ during the clean marine south-westerly air period 18-20 September 1998. Scatter plots for $\mathrm{CH}_{2} \mathrm{I}_{2}$ and $\mathrm{CH}_{2} \mathrm{IBr}$ concentrations with $\mathrm{TH}$ and $\mathrm{SR}$ for the whole campaign period are shown in Fig. 4. Strong evidence for these organic iodines as important photolytic precursors of IO is evident from their decreasing concentrations with solar flux and, during night-time, maxima at low tide. There is little correlation between $\mathrm{TH}$ and organo-iodine levels during the day, because of the strong influence of photolysis. Note that although peak concentrations of organo-iodines were observed at low water, both $\mathrm{CH}_{2} \mathrm{I}_{2}$ and $\mathrm{CH}_{2} \mathrm{IBr}$ exhibited 


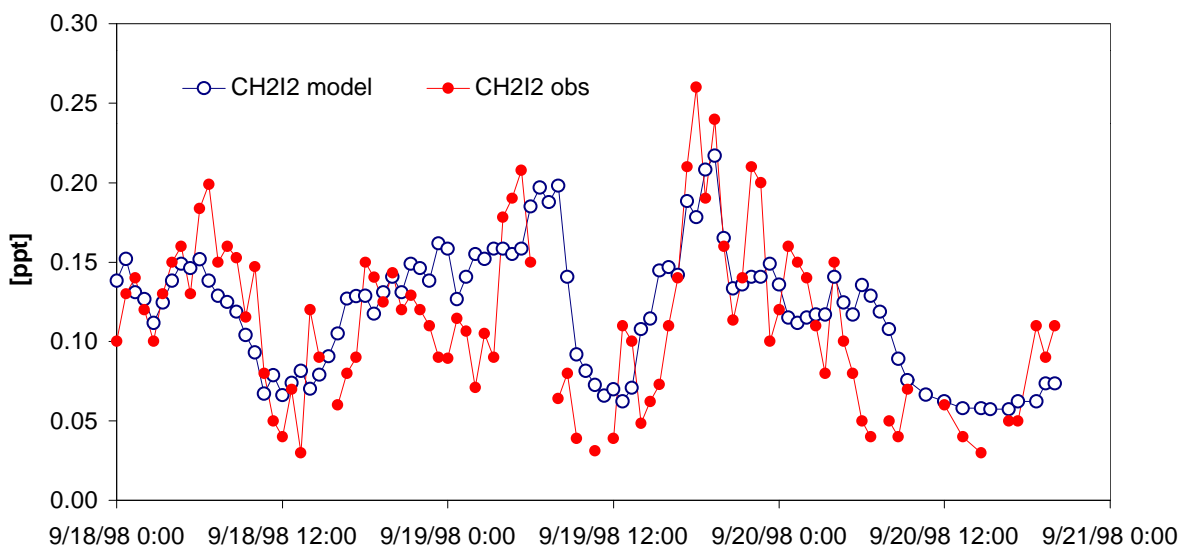

Fig. 7. Comparison of measured and modelled $\mathrm{CH}_{2} \mathrm{I}_{2}$ levels assuming only offshore emissions (40 minute averaged wind speed and $K$ ).

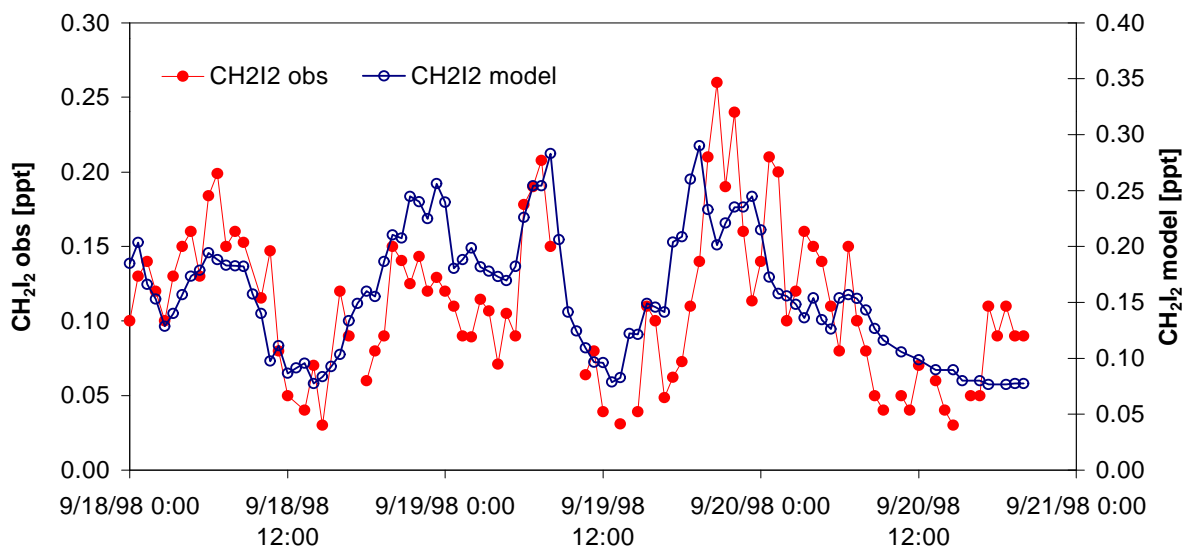

Fig. 8. Comparison of measured and modelled $\mathrm{CH}_{2} \mathrm{I}_{2}$ levels assuming both offshore and intertidal emissions (40 minute averaged wind speed and $K)$.

non-zero concentrations above their detection limits of 0.03 pptv even at high tide, presumably due to local sources, as discussed later. The dependence of $\mathrm{CH}_{2} \mathrm{I}_{2}$ on tidal height and solar radiation was found to be $\left[\mathrm{CH}_{2} \mathrm{I}_{2}\right]_{\text {night }}=0.17-$ $0.02[\mathrm{TH}]$ and $\left[\mathrm{CH}_{2} \mathrm{I}_{2}\right]_{\text {all }}=0.12-0.0013[\mathrm{SR}]$.

Given that the organoiodine precursors exhibited linear dependencies with $\mathrm{TH}$ at night, the cause of the exponential relationship of IO with TH (Fig. 2) does not appear to be explained by source variations and is possibly attributable to the photochemistry of IO. It should also be noted that the IO measurements represent averages over $\sim 7 \mathrm{~km}$, whereas the organoiodines were measured by point sampling.

\subsection{2-dimensional model simulations}

The initial model simulations incorporated only tidal emissions. The night-time $\mathrm{CH}_{2} \mathrm{I}_{2}$ vs TH negative trend, shown in Fig. 4, was presumed to be indicative of coastal production processes. Therefore the tidal dependence of the coastal flux was assumed to have the same qualitative form. A quan- titative fix was available from independent data on seaweed emissions, described below.

In addition to atmospheric measurements made during PARFORCE, the release rates of organic bromines and iodines from seaweeds were determined from incubations in seawater of ten species of brown, red and green macroalgae collected in the intertidal or subtidal zones of the rocky shore (Carpenter et al., 2000). The most prevalent seaweeds present in the intertidal zone at Mace Head, in common with most Northern European rocky shores (Michanek, 1975), were the brown algae Laminaria digitata, Laminaria saccharina and Ascophyllum nodosum. These algae are also among the most productive in terms of $\mathrm{CH}_{2} \mathrm{I}_{2}$ emissions, with mean production rates of $8.3,1.9$ and $0.36 \mathrm{pmol} \mathrm{g}^{-1}$ fresh weight $\mathrm{hr}^{-1}$, respectively (Carpenter et al., 2000). Estimates of total kelp density from data provided by the Irish Seaweed Industry Organisation (ISIO) are $11.6 \mathrm{~kg} \mathrm{~m}^{-2}$ (Carpenter et al., 2000). However this value includes Laminaria hyboborea, which is only present at depth, therefore the kelp density of the intertidal zone should be reduced by $\sim 25 \%$ (Carpenter 


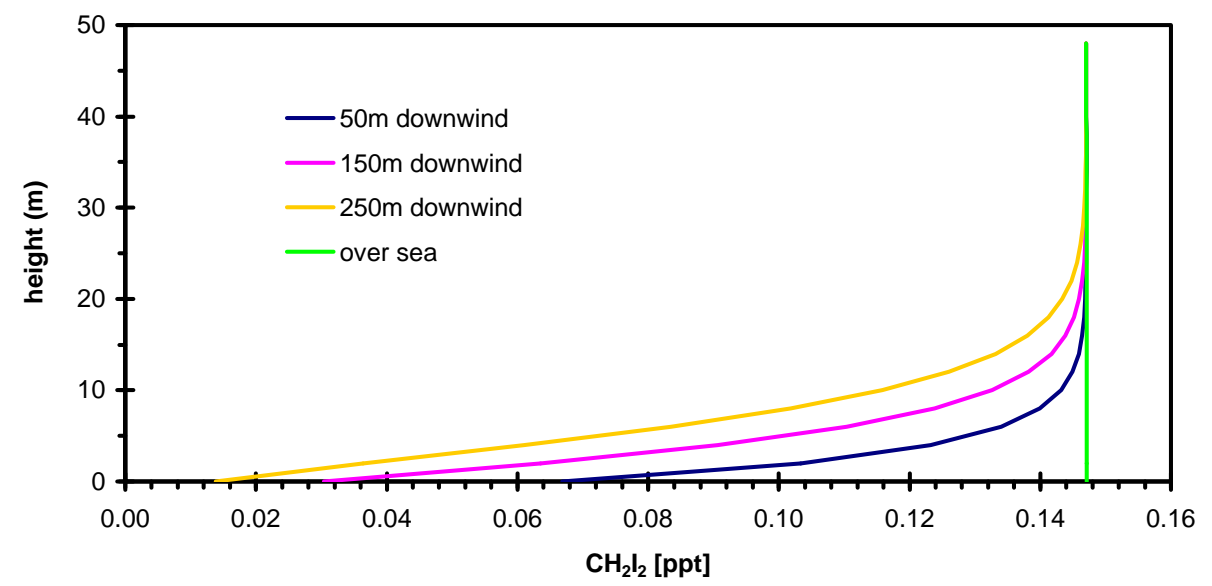

Fig. 9a. Gradient of $\mathrm{CH}_{2} \mathrm{I}_{2}$ mixing ratios predicted using the offshore flux scenario.

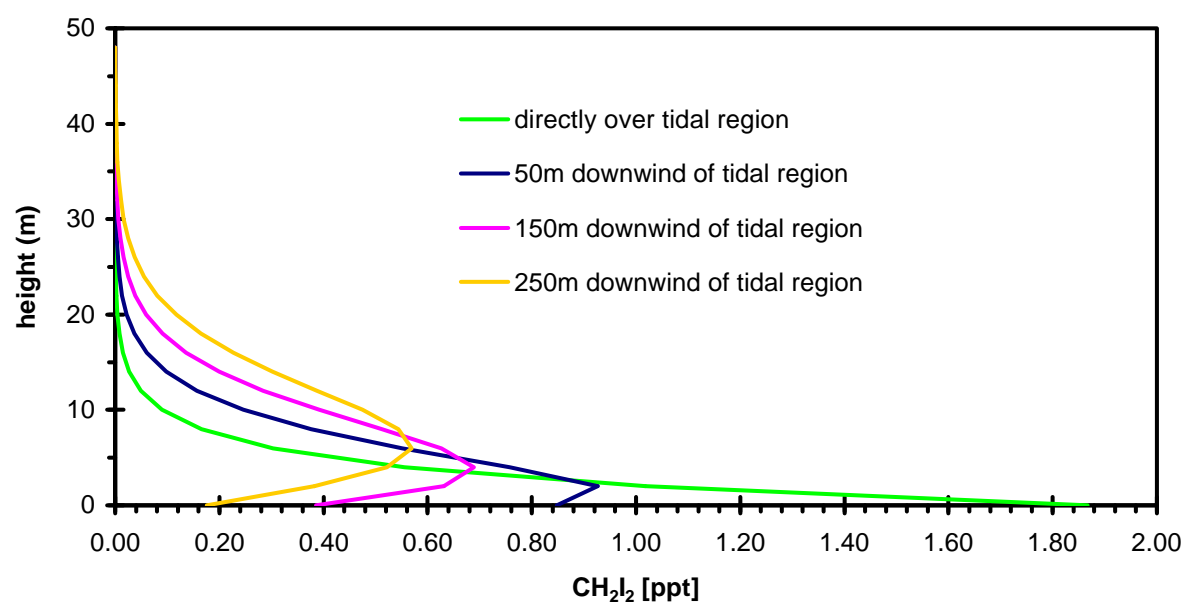

Fig. 9b. Gradient of $\mathrm{CH}_{2} \mathrm{I}_{2}$ mixing ratios predicted using the coastal flux scenario.

et al., 2000). Assuming the density is evenly spread between L. digitata, L. saccharina and A. nodosum and over the intertidal zone leads to a total $\mathrm{CH}_{2} \mathrm{I}_{2}$ emission rate of $\sim 1.5 \times 10^{9}$ molecules $\mathrm{cm}^{-2} \mathrm{~s}^{-1}$. This rate was used as the maximum coastal flux at the lowest tide. The high tide flux was assumed to be equal to the offshore flux, described below.

Figure 5 shows that the overall magnitude of the $\mathrm{CH}_{2} \mathrm{I}_{2}$ concentrations predicted by the model was in good agreement with the observed levels, indicating that estimation of the $\mathrm{CH}_{2} \mathrm{I}_{2}$ flux from seaweed emissions was a valid approach. However, there were clear discrepancies in some of the features. Also shown in Fig. 5 is the modelled intertidal flux used in this scenario. At night, the flux is closely correlated with the $\mathrm{CH}_{2} \mathrm{I}_{2}$ concentration, with small differences due to the variability in wind speed and eddy diffusivity. During the day, the modelled $\mathrm{CH}_{2} \mathrm{I}_{2}$ concentration is reduced relative to the tidal flux because of photolysis. However, the reduction due to photolysis was not sufficient to simu- late the observations, as is clearly seen during the last day of data. There are also other features not well represented by the model, such as the overestimation of $\left[\mathrm{CH}_{2} \mathrm{I}_{2}\right]$ during the night of the 18-19 September.

\subsection{Simulation of offshore emissions}

An alternative flux situation was investigated, wherein the offshore region was a source of $\mathrm{CH}_{2} \mathrm{I}_{2}$. The atmospheric concentration of $\mathrm{CH}_{2} \mathrm{I}_{2}$ predicted by the 2-dimensional model is related to the product of the magnitude of the flux and the length of the grid. It is therefore not possible to put a meaningful value on the magnitude of the offshore flux without knowing precisely the length of the upwind fetch. Although this was known to a reasonable degree for the tidal scenario (i.e. the intertidal range), the degree of open ocean production of $\mathrm{CH}_{2} \mathrm{I}_{2}$ is uncertain.

Ocean production of $\mathrm{CH}_{2} \mathrm{I}_{2}$ up to $5 \mathrm{~km}$ offshore of Mace Head was assessed from discrete surface seawater measure- 

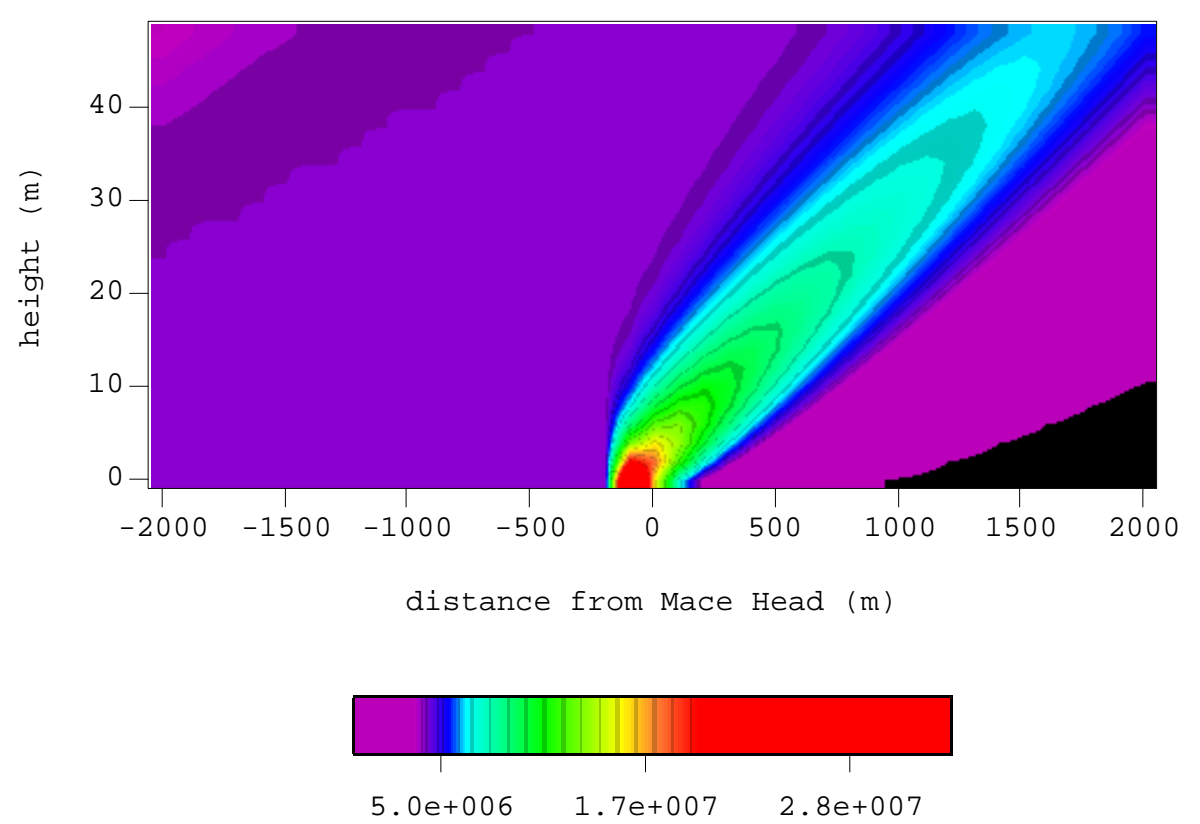

Fig. 10. Predicted variation in $\mathrm{CH}_{2} \mathrm{I}_{2}$ concentration gradients upwind (negative distances) and downwind (positive distances) of Mace Head at midnight. The colour scale represents the $\mathrm{CH}_{2} \mathrm{I}_{2}$ concentration in molecule $\mathrm{cm}^{-3}$, with black representing concentrations less than $1 \times 10^{5}$ molecule $\mathrm{cm}^{-3}$.

ments made during the 2 weeks immediately after the atmospheric measurements. Although there was a higher concentration of $\mathrm{CH}_{2} \mathrm{I}_{2}$ in seawater sampled directly over kelp beds then in areas with no seaweeds, there was no obvious relationship between distance from shore and dissolved $\mathrm{CH}_{2} \mathrm{I}_{2}$ concentration between $200 \mathrm{~m}$ and $5 \mathrm{~km}$ offshore. The average concentration over this region was $0.52 \pm 0.26 \mathrm{pmol} \mathrm{L}^{-1}$ (mean of 6 measurements) and the mean seawater temperature was $12^{\circ} \mathrm{C}$ (Carpenter et al., 2000). The equilibrium air concentration at this temperature calculated using the Henry's law coefficient for $\mathrm{CH}_{2} \mathrm{I}_{2}$ reported by Moore et al. (1995) is $0.1 \mathrm{pptv}$. Thus, it is difficult to assess whether or not the offshore waters of Mace Head were a source of $\mathrm{CH}_{2} \mathrm{I}_{2}$ or simply in equilibrium. An upper limit to the flux can however be calculated using a $\mathrm{CH}_{2} \mathrm{I}_{2}$ concentration in air of zero. From the Liss-Merlivat expression (Liss and Merlivat, 1986) with a square root molecular weight correction for the transfer velocity (Liss and Slater, 1974) and the mean wind speed, the flux is $2 \times 10^{5}$ molecules $\mathrm{cm}^{-2} \mathrm{~s}^{-1}$.

Because the offshore emissions and fetch are highly uncertain, we do not attempt here to provide an estimate of these emissions, but rather to provide an emission regime that results in good agreement with the measurements. Thus, the point of including an offshore scenario is to establish whether non-local sources of $\mathrm{CH}_{2} \mathrm{I}_{2}$ were present at Mace Head, and the possible contribution of these.

With a $5 \mathrm{~km}$ fetch of offshore emissions, a flux of $4 \times$ $10^{7}$ molecules $\mathrm{cm}^{-2} \mathrm{~s}^{-1}$ was required for good agreement of the overall levels of measured and modelled $\left[\mathrm{CH}_{2} \mathrm{I}_{2}\right]$, as shown in Fig. 6. Because a fetch of at least up to $5 \mathrm{~km}$ offshore was established by the seawater measurements, this flux can be taken as an upper limit. Note, however, that the same agreement would have been possible with the estimated flux of $2 \times 10^{5}$ molecules $\mathrm{cm}^{-2} \mathrm{~s}^{-1}$ and a fetch of about $1000 \mathrm{~km}$. The model predictions shown in Fig. 6 were made assuming constant wind speed and eddy diffusivity (averages for the period). The model reproduced the daytime reductions in $\left[\mathrm{CH}_{2} \mathrm{I}_{2}\right]$ due to photolysis, indicating that nonlocal sources were indeed an important contribution to the atmospheric levels at Mace Head. However, the peak levels of $\mathrm{CH}_{2} \mathrm{I}_{2}$ were not replicated well by the model. The simulation was repeated using 40-minute averages of wind speed and eddy diffusivity. Figure 7 shows that the inclusion of micrometeorological variability resulted in significantly improved agreement with the measurements. Clearly, meteorological parameters also played a large part in controlling the variability in $\mathrm{CH}_{2} \mathrm{I}_{2}$ concentrations at Mace Head.

The result of including both coastal and offshore fluxes in the model is shown in Fig. 8. Although the combination of fluxes resulted in an overestimation of modelled $\mathrm{CH}_{2} \mathrm{I}_{2}$ concentrations by $\sim 30 \%$, the correlation between modelled and measured data was greater than that of either the separate flux scenarios. For ten-point averages of modelled vs measured data, the $r^{2}$ values were 0.89 (coastal + offshore), 0.78 (offshore only) and 0.75 (coastal only). 


\subsection{Prediction of spatial variation of $\mathrm{CH}_{2} \mathrm{I}_{2}$ concentrations}

The horizontal domain of the model was extended by $2 \mathrm{~km}$ in order to examine the dispersion of $\mathrm{CH}_{2} \mathrm{I}_{2}$ downwind from the shore. Both the coastal and offshore flux scenarios gave rise to similar levels of $\mathrm{CH}_{2} \mathrm{I}_{2}$ at Mace Head at $12 \mathrm{~m}$ height. However, the vertical profiles predicted were very different, as shown in Figs. 9a and 9b. The offshore source resulted in a constant $\mathrm{CH}_{2} \mathrm{I}_{2}$ concentration vertical gradient over the open sea, but a rapidly increasing concentration with height over Mace Head, $150 \mathrm{~m}$ downwind of the shore. Conversely, over a few metres height, the tidal source gave rise to decreasing $\mathrm{CH}_{2} \mathrm{I}_{2}$ levels over Mace Head, $50 \mathrm{~m}$ downwind of the tidal region (i.e. the mid point of the $100 \mathrm{~m}$ cell adjacent to the $100 \mathrm{~m}$ tidal region). Internal boundary layer formation would lead to perturbations of these modelled gradients.

Figure 10 shows the predicted $\mathrm{CH}_{2} \mathrm{I}_{2}$ concentrations from $2 \mathrm{~km}$ upwind of the site to $2 \mathrm{~km}$ downwind at midnight in westerly (marine) air. Considerable heterogeneity is expected over the few hundred metres downwind. Measurements in both the horizontal and vertical domains at Mace Head are planned to test these predictions.

\section{Summary and conclusions}

Strong evidence for the organoiodines $\mathrm{CH}_{2} \mathrm{I}_{2}$ and $\mathrm{CH}_{2} \mathrm{IBr}$ as photolytic precursors to the IO radical at Mace Head was shown from the dependence of the atmospheric concentrations of all three species on tidal height. Iodine oxide concentrations peaked at low water during midday hours and the reactive organoiodines, whose atmospheric lifetimes are less than 1 hour at midday, peaked when low water coincided with night.

The intertidal flux of $\mathrm{CH}_{2} \mathrm{I}_{2}$ upwind of Mace Head was estimated from seaweed emissions and used in a 2-dimensional model to predict the $\mathrm{CH}_{2} \mathrm{I}_{2}$ concentrations in marine air at Mace Head. This flux resulted in good agreement between the mean concentrations of measured and modelled $\mathrm{CH}_{2} \mathrm{I}_{2}$, but did not reproduce well the daytime depletion due to photolysis. A non-local, offshore, source of $\mathrm{CH}_{2} \mathrm{I}_{2}$ was invoked, which did reproduce the daytime depletion. Three separate scenarios of offshore sources alone, tidal sources alone, and offshore plus tidal sources were used as inputs to the model. The model showed that variability in wind speed and friction velocity, proximity to source, and photolysis all played important roles in determining the $\mathrm{CH}_{2} \mathrm{I}_{2}$ concentrations at the site. The best agreement with the $\mathrm{CH}_{2} \mathrm{I}_{2}$ observations was obtained using constrained micrometeorological fields, and a combination of a constant offshore flux and a tidal flux that peaked at $1.4 \times 10^{9}$ molecules $\mathrm{cm}^{-2} \mathrm{~s}^{-1}$ at low water.

Because the atmospheric concentration of $\mathrm{CH}_{2} \mathrm{I}_{2}$ predicted by the 2-dimensional model was related to the length of the upwind fetch, a meaningful value cannot be assigned to the offshore emission rate, although we estimate an upper limit of $4 \times 10^{7}$ molecules $\mathrm{cm}^{-2} \mathrm{~s}^{-1}$. Rather, we conclude that a contribution from both intertidal and offshore sources is likely, with the tidal flux being several orders of magnitude higher. Although this study cannot predict whether $\mathrm{CH}_{2} \mathrm{I}_{2}$ is emitted from the open ocean, it suggests that it does undergo air-sea exchange in coastal waters despite its presumably rapid photolysis rate.

Acknowledgements. We are grateful to Gerrit de Leeuw for supplying micro-meteorological data from PARFORCE, and to Jochen Stutz and Gerd Hönninger for their help performing the DOAS measurements and the evaluation of the DOAS data. We would also like to acknowledge Colin O'Dowd, Gerry Spain and Mick Geever for their organization of the PARFORCE campaign. Financial support for this project was provided by the Natural Environment Research Council (NERC) grant GR9/03597.

\section{References}

Alicke B., Hebestreit, K., Stutz, J., and Platt, U.: Iodine oxide in the marine boundary layer, Nature, 397, 572-573, 1999.

Allan B. J., McFiggans, G., Plane, J. M. C., and Coe, H.: Observations of iodine monoxide in the remote marine boundary layer, J. Geophys. Res., 105, 14 363-14 369, 2000.

Barrie, L. A., Bottenheim, J. W., Schnell, R. C., Crutzen P. J., and Rasmussen, R. A.: Ozone destruction and photochemical reactions at polar sunrise in the lower Arctic atmosphere, Nature, 334, 138-141, 1988.

Barrie, L.A. and Platt, U.: Arctic tropospheric chemistry: an overview, Tellus, 49B, 450-454, 1997.

Bottenheim, J. W., Barrie, L. A., Atlas, E., Heidt, L. E., Niki, H., Rasmussen, R. A., and Shepson, P. B.: Depletion of lower tropospheric ozone during Arctic spring: The Polar Sunrise Experiment, J. Geophys. Res., 95, 18 555-18 568, 1990.

Brauers, T., Hausmann, M., Brandenburger, U., and Dorn, H.-P.: Improvement of Differential Optical Absorption Spectroscopy with a multichannel scanning technique, Applied Optics, 34, 4472-4479, 1995.

Carpenter, L. J. and Liss, P. S.: On temperate sources of bromoform and other reactive organic bromine gases, J. Geophys. Res., 105, 20, 539-548, 2000.

Carpenter, L. J., Sturges, W. T., Liss, P. S., Penkett, S. A., Alicke B., Hebestreit, K., and Platt, U.: Short lived alkyl-iodides and bromides at Mace Head: Links to macroalgal emission and halogen oxide formation, J. Geophys. Res, 104, 1679, 1999.

Carpenter, L. J., Malin, G., Kuepper, F., and Liss, P. S.: Novel biogenic iodine-containing trihalomethanes and other short-lived halocarbons in the coastal East Atlantic, Global Biogeochem. Cycles, 14, 1191-1204, 2000.

Cox, R. A., Bloss, W. J., Jones, R. L., and Rowley, D. M.: OIO and the Atmospheric Cycle of Iodine, Geophysical Research Letters, 26, 13, 1857-1860, 1999.

De Leeuw, G., Kunz, G. J., and O’Dowd, C. D.: Micrometeorological measurements at the Mace Head mid-latitude coastal station, Submitted to J. Geophys. Res., 2001.

Friess, U., Wagner, T., Pundt, I., Pfeilsticker, K., and Platt, U.: Spectroscopic Measurements of Tropospheric Iodine Oxide at Neumayer Station, Antarctica, Geophys. Res. Lett., 28, 10, 1941-1944, 2001. 
Gschwend, P. M., Macfarlane J. K., and Newman, K. A.: Volatile halogenated organic-compounds released to seawater from temperate marine macroalgae, Science, 227, 1033-1035, 1985.

Harder, J. W., Brault, J. W., Johnston, P. V., and Mount, G. H.: Temperature dependent $\mathrm{NO}_{2}$ cross sections at high spectral resolution, J. Geophys. Res., 102, 3861-3879, 1997.

HITRAN,: HITRAN database 1986 edition, Applied Optics, 26, 4058-4097, 1987.

Hönninger, G.: Referenzspektren reaktiver Halogenverbindungen für DOAS Messungen, Diploma thesis, Ruprecht Karls Universität Heidelberg, Heidelberg, 1999.

Hough, A. M.: The calculation of photolysis rates for use in global troposheric modelling studies, AERE Report R-13259, 53, HMSO, London, 1988.

Klick, S. and Abrahamsson, K.: Biogenic volatile iodated hydrocarbons in the ocean, J. Geophys. Res., 97, 12 683-12 687, 1992.

Kunz, G. J., Cohen, L. H., and de Leeuw, G.: Lidar and micrometeorological measurements during the PARFORCE experiments at the Mace Head Atmospheric Research Station, Carna, Ireland, during September and June 1998, TNO Physics and Electronics Laboratory, Report FEL-00-C103, 2000.

Liss, P. S. and Merlivat, L.: Air-sea exchange rates: Introduction and synthesis, in: Role of Air-Sea Exchange in Geochemical Cycling, (Ed) Buat-Ménard, P., D. Reidel Publishing Company, Dordrecht, 113-127, 1986.

Liss, P. S. and Slater, P. G.: Flux of gases across the air-sea interface, Nature, 247, 181-184, 1974.

McFiggans, G., Allan, B., Coe, H., Plane, J. M. C., Carpenter, L. J., and O'Dowd, C., Observations of IO and a modelling study of iodine chemistry in the marine boundary layer, J. Geophys. Res., 105, 14, 371-385, 2000.

Michanek, G.: Seaweed resources of the ocean, FAO Fish. Tech. Pap., 138, 127, 1975.

Moore, R. M., Geen, C. E., and Tait, V. K.: Determination of
Henry's Law constants for a suite of naturally occurring halogenated methanes in seawater, Chemosphere, 30, 1183-1191, 1995.

Mössinger, J., Shallcross, D. E., and Cox, R. A.: UV-visible absorption cross-sections and atmospheric lifetimes of $\mathrm{CH}_{2} \mathrm{Br}_{2}, \mathrm{CH}_{2} \mathrm{I}_{2}$, and $\mathrm{CH}_{2}$ BrI, J. Chem. Soc. Far., 10, 1391-1396, 1998.

Nightingale P. D., Malin, G., and Liss, P. S.: Production of chloroform and other low-molecular-weight halocarbons by some species of macroalgae, Limnol. Oceanogr., 40, 680-689, 1995.

Pedersén, M., Collén, J., Abrahamsson, K., and Ekdahl, A.: Production of halocarbons from seaweeds-an oxidative stress reaction, Scientia Marina, 60, 257-263, 1996.

Platt, U.: Differential optical absorption spectroscopy (DOAS), Chemical Analysis Series, 127, 1994.

Platt, U. and Perner, D.: Measurements of atmospheric trace gases by long path differential UV/visible absorption spectroscopy, in: Optical and Laser Remote Sensing, (Eds) Killinger, D. A. and Mooradien, A., Springer Verlag, New York, 95-105, 1983.

Schall, C., Heumann, K. G., and Kirst, G. O.: Biogenic volatile organoiodine and organobromine hydrocarbons in the Atlantic Ocean from 42 degrees $\mathrm{N}$ to 72 degrees S, Fresenius J. Anal. Chem., 359, 298-305, 1997.

Stull, R. B.: An introduction to boundary layer meteorology, Kluwer Academic Publishers, Dordrecht, 1988.

Stutz, J. and Platt, U.: Improving long-path differential optical absorption spectroscopy with a quartz-fiber mode mixer, Applied Optics, 36, 1105-1115, 1997.

Stutz, J., Hebestreit, K., Alicke, B., and Platt, U.: Chemistry of halogen oxides in the troposphere: comparison of model calculations with recent field data, J. Atmos. Chem., 34, 65-85, 1999.

Vogt, R., Sander, R., von Glasow, R., and Crutzen, P. J.: Iodine chemistry and its role in halogen activation and ozone loss in the marine boundary layer: A model study, J. Atmos. Chem., 32, 375-395, 1999. 